\title{
LITERACY ACTIVITIES OF SPECIAL NEED STUDENT: A CASE STUDY IN SOLVING READING COMPREHENSION FOR ADHD STUDENT
}

\author{
Novi Rahmania Aquariza \\ Nahdlatul Ulama University Surabaya \\ e-mail: novirahmania@unusa.ac.id
}

\begin{abstract}
Language teachers have many ways to make the teaching and learning process become more interesting, especially in teaching the students with the special need. One of this types known as ADHD (Attention Deficits Hyperactive Disorder) will be discussed in this paper. The student with this type of special need has a special ways too in their teaching and learning process. In this case, reading comprehension. Reading is well known as one of the literacy activities. Make the students literate is very important no matter who the student is. Thus the special need student also has a right to be literate too through the literacy activities. This paper focuses on describing the teaching and learning process of reading using comic strip. The discussion is about the way it conducts in a class, the steps and also the materials used. The data were collected by documentation, observation, and interview; and, analyzed using qualitative description. The results show that comic strip is able to build an enthusiasm of the student. It is because comic strip is interesting for him. It automatically helps him to predict the content of the text given. Thus, through the use of comic strip, the problems related to the reading comprehension of special need students are solved gradually.
\end{abstract}

Keywords: comic strip, ADHD, reading comprehension, literacy activities

\begin{abstract}
Abstrak: Seorang guru bahasa hendaknya memiliki banyak cara untuk membuat proses belajar mengajar menjadi menarik, utamanya ketika menghadapi siswa berkebutuhan khusus. Satu di antaranya adalah pada kasus ADHD (Attention Deficits Hyperactive Disorder) yang akan didiskusikan pada artikel ini. Siswa dengan kebutuhan khusus tipe ini juga memiliki cara tersendiri dalam proses belajar dan mengajar mereka. Sebagai contoh, dalam hal membaca. Membaca diketahui sebagai salah satu kegiatan literasi. Menjadikan siswa sadar literasi sangat penting, tidak peduli bagaimanapun kondisi siswa tersebut. Sehingga, siswa berkebutuhan khusus sekalipun memiliki hak untuk menjadi seseorang yang sadar literasi melalui kegiatan literasi. Artikel ini mendeskripsikan proses belajar mengajar Reading menggunakan Comic Strip. Pembahasannya meliputi bagaimana penerapan Comic Strip di kelas, tahapan-tahapannya dan materi apa yang dibutubkan. Data dihimpun melalui dokumentasi, observasi dan wawancara yang kemudian dianalisis secara deskriptif. Hasil yang diperoleh menunjukkan bahwa Comic Strip cukup menarik bagi siswa berkebutuhan khusus tipe ADHD. Comic Strip membantu siswa tersebut memprediksi isi bacaan. Sehingga problematika yang timbul ketika Reading dapat teratasi.
\end{abstract}

Kata kunci: comic strip, ADHD, reading comprehension, literacy activities

\section{INTRODUCTION}

\section{Background}

For an English teacher, it is a challenge to teach a student with special need. There must be special strategy and special media too. Be- cause teaching special student is quite different from teaching normal student as usual. Remembering that reading is an important skill in teaching and learning language, thus the teacher must pay attention to this. 
The ability to read is one of the most significant requirements for academic success (Thomas, 1996). Students' ability to read sometimes shows their level of knowledge acquisition and skills; students with poor reading skills have more difficulty in school. Even more important, limited reading ability hinders the student from having a normal standard of life, and that can be a great disadvantage to them in finding vocational opportunities, for instance. (Alnahdi \& Sattam, 2015) As one of literacy activities, reading is very important not merely in school academic learning but also to lifelong learning. In order to be able to read, people need go through the process of decoding written words and comprehend them.(Keller \& Abuelhassan, 2015)

Special need student discussed in this paper is the student with Attention Deficits Hyperactive Disorder (ADHD). Those face difficulties in controlling attention. Some studies like Richards and colleagues in 1990 observed that students with ADHD seemed to have more difficulties with sustain attention, whereas those with learning disabilities have problems with selective attention. Other studies show that students with ADHD also have difficulties in selective attention since they get distracted easily or select irrelevant stimuli. (Keller \& Abuelhassan, 2015)

It can be identified that they must have some difficulties in reading. Then, it will be better when the English teacher put a variation on it. Improving the students reading skill and help them to understand the content of the text sometimes is not easy. The teacher still should be face the problem that may arises. Despite students are not interested, sometimes they are complaining that they can't figure out anything to understand and less motivation in reading. Furthermore, they may have a problem in mastery the vocabularies.

There are many ways conducted by English Teachers to minimize the problem arise during the teaching reading for special need students. Some of them may tend to use the certain media and strategies to help them in making the teaching and learning process esier, so that the learning objectives can be reached.

In line with statement above, the researcher consider comic strip as the solution in solving special need students' literacy activities. The teacher can use comic strips to introduce and to illustrate the text. Comic strips are useful for both reading and writing practice. The teacher can combine comic strips with writing by having students make comics with pictures and bubble comic strip boxes to fill in.

The use of comics in teaching is allowd. The most teachers can do is to take note of the preoccupations this culture testiûes to in his pupils' make-up and then try to ûnd and make available as many books as he can (the more recent in publication date the better) which engage with these preoccupations in a mode which is both more sensitive and constructive. (Whitehead et al. 1977, p. 185)(“. Jackie Marsh, Elaine M Millard-Literacy and Popular Culture_Using Children's Culture in the Classroom (2001).pdf," n.d.)

This paper describes the way teacher conducts the comic strip in an effort to solve special need students' reading skill, on of the literacy activities. The special need student in this paper refers to the freshman student of English Department named X. The response by the students towards the use of the comic strip given by the teacher is included too. 


\section{Problems}

On a level with the research background, the problem of this research can be formulated as:

1. What is $\mathrm{X}$ problem on reading comprehension?

2. How to apply comic strip in solving the reading comprehension for $\mathrm{X}$ ?

3. To what extent does the comic strip contribute to learning objective.

\section{Objectives}

Concerning the above problems, the research aims:

1. To describe $\mathrm{X}$ problem on reading comprehension.

2. To describe the implementation of comic strip in solving the reading comprehension for X.

3. To describe the contribution of comic strip in learning objective.

\section{Significance}

Perceived by the objectives above, this research tries to provide English teachers with the appropriate procedures of solving the special need students' reading comprehension through comic strip.

\section{Definition of Key Terms}

In order to avoid misinterpretation, the following key terms used in this research will be defined:

1. Comic strip refers to a media used by the teacher in reading comprehension for special need student.

2. X refers to the special need student, he is the freshman student of English Department with (Attention Deficits Hyperactive Disorder) ADHD problem

3. Literacy activities refer to reading comprehension activity conducted in a class of observation.

\section{REVIEW OF RELATED LITERATURE}

\section{Teaching Reading Strategies}

Teaching reading strategies may vary from one teacher to another. Teacher sometimes use word card vocabulary in order to stimulate students' prior knowledge. Furthermore, reading strategy can be described as any interactive process of getting meaning from the text. Teaching reading strategies by English teachers can help students to have better understanding on the text that they read as well as in learning reading English (Mahmud, 2008). The better strategy used by the teacher, the more effective teaching reading obtained.

Common teaching reading strategy named scanning and skimming the text and also silent reading. those strategy are familiar and mostly used by the teacher ("The Correlation Between Reading Habit in English and Reading Comprehension at Second Semester of IAIN Tulungagung Academic Year,” 2014).

In this digital era it's not difficult anymore for the teacher to find out the media or match the strategy for teaching reading. The article or certain text which easily can be accessed from handphone can be one of the sources for teaching reading media. It is so close to them and everyone posibble to reach it. The existence of the digital literacy nowadays may inspired the teacher to use it as the supporting of the strategy for teaching reading. 


\section{The Problems Related to Teaching Reading}

There are several problems involved in getting students to read and understanding the text. Mostly, students are reluctant with the readig task or assignment. It is because rading is not interesting for some of them. The text offered is sometimes the text that they don't want to read.

Some of them has a lackness in vocabulary mastery, so it is not easy for them to read the text and figure out the aim of the text. Another problem arise during the teaching reading comprehension is about the motivation. Sometimes the student has less motivation in reading because reading is not their habbit. Thus they don't have passion to read the text. Frankly most of the students read for the certain purposes, not for their knowledge or for developing themselves.

Reading is very important for the student, they realize it but it is hard to build the reading habbits and sometimes easy to start reading for self development.

\section{Reading as one of Literacy activities for Special Need Student}

Teaching reading for special need student is much more challenging than teaching reading for normal students. In this paper, special need student refers to the student with Attention Deficits Hyperactive Disorder (ADHD).

In the normal condition, this student has a difficulty to focus on something. It can be imagined that it is also not easy for them if they have to read a text, focus on it and understanding the aim of it.

First of all if we want to help them to read means that we have to deals with their attention. Focus on it. It is in line with Keller's statement that there are some medications to improve attention in students with ADHD. However, it is important to use medication combined with behavioral interventions in order to maintain the effect for longer periods (Miranda et al., 2006). One of the effective behavioral intervention model for students with ADHD is Self-Regulation Strategies Development (SRSD). (Keller \& Abuelhassan, 2015)

The statement above is also supported by the stages related, consist of developing active background knowledge for a specific strategy, discussing the strategy, modeling it, making students memorize it, supporting it, and help students to independently performing it. For example: 1) In the stage of developing background knowledge, teachers develop any preskill knowledge, such as vocabulary or concepts that help in learning the strategy. 2) In the discussing stage, teachers and students discuss the strategy. Also, in this stage, the importance of student efforts should be emphasized in order to increase motivation and develop positive attribution to the strategy. 3) In the modeling stage, the teacher model the strategy and types of self-instructions. Type of self-instruction includes problem definition (i.e., what is it I have to do here?), focusing attention and planning (i.e., I have to concentrate, first, I need to...then...), self-evaluation and error correcting (i.e., have I used all my parts?), selfreinforcement (i.e., I like this ending). 4) In the memorizing stage, students are supported to memorize the strategy. They are told that if they cannot memorize it, they will not be able to use it. 5) In the stage of independent performance, students are supported to practice the strategy using scaffolding. Scaffolding is supporting the students until they master a skill. 6) Students need to independently practice the strategy. These stages can be helpful to students with ADHD because it improves their attention 
and help them monitor and regulate themselves (Keller \& Abuelhassan, 2015).

\section{METHOD}

This paper supposed to describe a classroom situation at the time that the teacher gives the comic strip in an effort of solving the special need student's reading problem. The data were obtained from a Reading class of freshmen taught by a female lecturer. They were collected by an observation.

The steps of data analysis process after data collections are: Describing the materials used and describing the activities that lecturer and student did in the classroom during the teaching and learning process. It was involved the lecturer's act of teaching while using the comic strip, the student's responses, describing the problems in the teaching learning process and the also the advantages of using comic strips.

\section{FINDINGS AND DISCUSSIONS}

The observation conducted in a reading activity that representing the competency of cause and effect as stated on the syllabus and the Lesson Plan. This mini research is inspired by Keller's stage in focusing the attention of ADHD student as an effort of the reading comprehension problem.

The teaching reading in this class designed to facilitate the student to be interested in reading. The researcher use comic strip as a media in teaching reading for this student in order to get his attention. Moreover, the implementation of the comic strip here was so helpful to support the student in dealing with his ideas and creativity. This session will quite explain the procedures related to the implementa- tion of comic strip in reading activity based on the class observation result. Among them are the following:

- At pre teaching of each meeting, the lecturer was conducting three activities namely: greet and check students' presence, and reviewing the previous lesson.

- Then, the lecturer gives a comic strip to $\mathrm{X}$ (the ADHD student). The lecturer explain some instruction followed the comic strip given.

- X sees the comic strip at glance and shows his interest. He starts doing something with that comic strip.

- The lecturer ask him to write what he sees on vomic strips.

- He write down his answer by very simple words. In this stage means that he predict the story of comic strips.

- The lecturer evaluate X answers.

- The lecturer tells him that the comic strips reflects the text, and check the accuracy of $\mathrm{X}$ prediction toward the text through the comic strip.

Problems appeared during the use of comic strip, sometimes it is not easy to find out the comic strip that can support the text. Another problem is, this kind of student is unpredictable. Sometimes he pays attention but sometimes he has a problem with his emotion. It influence the teaching and learning process the most. Comic strips provide almost of the student's need to be more literate. It gives the students a chance to understand the text by a pprediction through the comic strip.

For an English teacher, the comic strip also becomes a source to support their teaching strategy. Successful teaching means giving the lessons and that's why transferring is guaranteed. Less understanding means less transfer- 
ring, more understanding means more transferring. These facts force the teacher to make an effective effort to produce a good teaching process to their students.

\section{CONCLUSION}

Through this paper, the idea that comic strip is able to solve the special need students' reading comprehension problem is proven. There are some requirements so that the teaching-learning process is running well by comic strip, such as: the materials should be well selected, and the lecturer has to make sure that the activities should be appropriately designed. The materials and the activities not only will improve students' reading enthusiasm but also increase the confidence and creativity.

\section{REFERENCES}

._Jackie Marsh, Elaine M. Millard. 2001. Literacy and Popular Culture_Using Children's Culture in the Classroom. pdf. (n.d.).

Alnahdi, G. H., \& Sattam, P. 2015. Teaching Reading for Students with Intellectual Disabilities/ : A Systematic Review, 8(9), 7987. https://doi.org/10.5539/ies.v8n9p79

Keller, C.E. \& Abuelhassan, H.H. 2015. Improving Reading Comprehension for Students with ADHD, 2(1), 44-51.

"The Correlation Between Reading Habit in English and Reading Comprehension at Second Semester of IAIN Tulungagung Academic Year." (2014), 12-36. 